\title{
The Ghana Community-based Health Planning and Services Initiative: Fostering evidence-based organizational change and development in a resource-constrained setting
}

Frank K. Nyonator

John Koku Awoonor-Williams

James F. Phillips

Population Council

Tanya C. Jones

Population Council

Robert A. Miller

Population Council

Follow this and additional works at: https://knowledgecommons.popcouncil.org/departments_sbsr-pgy

Part of the Demography, Population, and Ecology Commons, Family, Life Course, and Society

Commons, and the International Public Health Commons

How does access to this work benefit you? Let us know!

\section{Recommended Citation}

Nyonator, Frank K., John Koku Awoonor-Williams, James F. Phillips, Tanya C. Jones, and Robert A. Miller. 2003. "The Ghana Community-based Health Planning and Services Initiative: Fostering evidence-based organizational change and development in a resource-constrained setting," Policy Research Division Working Paper no. 180. New York: Population Council. Version of record: https://doi.org/10.1093/heapol/ czi003 
The Ghana Community-based

$>$ Health Planning and Services



e Initiative: Fostering Evidence-based Organizational Change and

Frank K. Nyonator

J. Koku Awoonor-Williams

James F. Phillips

Tanya C. Jones

Robert A. Miller

$\succ$

$\cup$

$\mapsto$

$\mapsto$

0

$\Leftrightarrow$ 


\title{
The Ghana Community-based Health Planning and Services Initiative: Fostering Evidence-based Organizational Change and Development in a Resource-constrained Setting
}

\author{
Frank K. Nyonator \\ J. Koku Awoonor-Williams \\ James F. Phillips \\ Tanya C. Jones \\ Robert A. Miller
}

Frank K. Nyonator, is Director, Policy, Planning, Monitoring, and Evaluation Division, Ghana Health Service, Accra. J. Koku Awoonor-Williams is District Director of Medical Services, Nkwanta District, Nkwanta, Volta Region, Ghana. James F. Phillips is Senior Associate and Tanya C. Jones is Staff Associate, Policy Research Division, and Robert A. Miller is Senior Program Associate, International Programs Division, Population Council.

This paper was made possible through support provided by the Office of Population, Bureau for Global Programs, Field Support, and Research of the United States Agency for International Development, under the terms of Award No. HRN-A-00-99-00010. 


\begin{abstract}
Research projects demonstrating ways to improve health services often fail to have an impact on what national health programs actually do. An approach to evidence-based policy development has been launched in Ghana that bridges the gap between research and program implementation. The Community-based Health Planning and Services (CHPS) initiative employs strategies tested in the successful Navrongo experiment to guide national health reforms that mobilize volunteers, resources, and cultural institutions to support community-based primary health care. Over the 1999 to 2002 period, 100 out of the 110 districts in Ghana adopted a CHPS initiative. This paper reviews features of the initiative that explain its success and constrain future progress.
\end{abstract}

This material may not be reproduced without written permission from the authors. For a list of Policy Research Division Working Papers, including those available for downloading in PDF format, see www.popcouncil.org/publications/wp/prd/rdwplist.html. 
Exhortations to improve management, make use of research, and decentralize authority are commonplace. Among the best-known of them was the 1978 Global Health Conference call for "health for all" by the year 2000. Although health policy intended to address primary health-care needs has been in place for 20 years, demonstrations of how to achieve health for all are rare. Rarer still are examples of how research-based demonstrations can guide national health-sector reform. This paper reports on a program of evidence-based organizational change that has overcome the gap between research and action. The Ghana Community-based Health Planning and Services (CHPS) initiative is a program designed to translate innovations from an experimental study of the Navrongo Health Research Centre (NHRC) into a national program for improving the accessibility, efficiency, and quality of health and family planning services (Binka et al. 1995; Pence et al. 2001; Debpuur et al. 2002). With the advent of the CHPS initiative, the Navrongo experiment became the operational model for health-care development in Ghana. Originally launched by the Ministry of Health in 1994, the Navrongo Community Health and Family Planning Project addressed a long-standing commitment to improve access to primary health care. Despite the existence for two decades of "health for all" policies, in 1990 more than 70 percent of all Ghanaians still lived more than eight kilometers from the nearest provider, and rural infant mortality rates were 50 percent higher than corresponding urban rates (MOH 1998). Improving access to health-care delivery, therefore, remained a primary goal of health-sector reform in the 1990s. Research on accessible health care remained a priority, because none of the policy options for community-based care had been evaluated for its relative impact on health, mortality, and fertility.

In response to the need for improved primary health care, a phased program of research was launched to guide the process of changing the system from a clinical facility-focused approach to a community-based approach. The objective of the initiative from its beginning was operational change; research was viewed as a tool for guiding a general reform process by identifying underused cultural and organizational resources, assessing the impact of mobilizing these resources, and guiding health-system reform on the basis of lessons learned. National policies for health-care reform during this period were guided by the "sector-wide approach" mandated by the World Bank for integrating health-care planning, services, and budgets (Adjei et al. 2002). At its core, the 
Ghana Community-based Health Planning and Services initiative brought to an end various vertical programs and established mechanisms for the decentralized administration of health care. This initiative involves a process of evidence-based organizational change for extending the logic of the sector-wide approach to the community level. In order to foster the transition from facility- and component-focused health care to integrated community-based health services, the CHPS initiative has three arms (see Figure 1): (1) a research arm that provides evidence for guiding the process; (2) an arm that provides policies, resources, and mechanisms for communicating the process and priorities for operational change; and (3) an arm comprising informal mechanisms for spreading innovation and change between and within districts. In 1999, the Ghana Health Service (GHS) was instituted to assume responsibility for operations. The Navrongo Health Research Centre became an institution of the Ghana Health Service, and the CHPS program was launched as a GHS initiative.

Figure 1 Components of the CHPS process

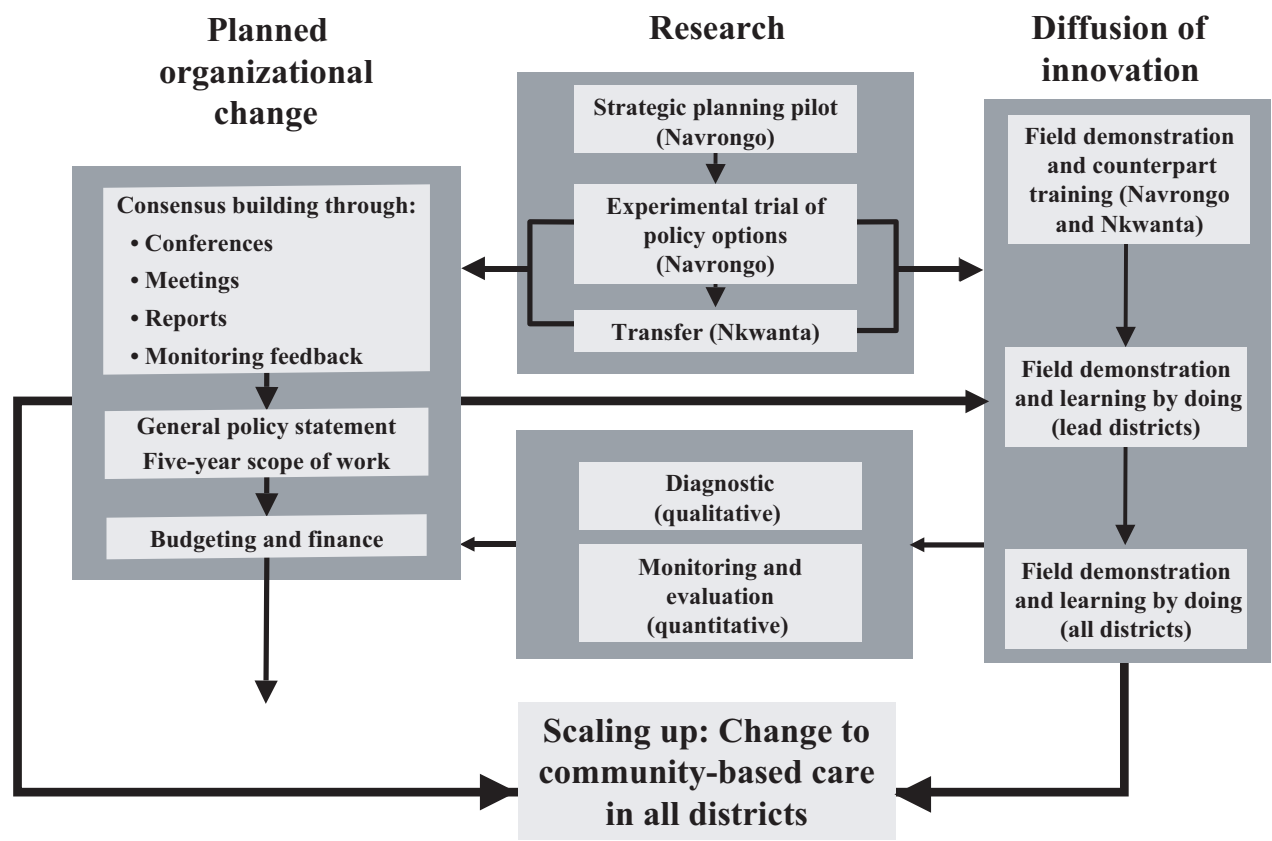




\section{THE ROLE OF RESEARCH}

\section{The Navrongo Experiment}

Research in the CHPS program has proceeded by stages, each with a role in developing policy. The first phase, launched in 1994, involved convening a GHS task force to guide a Navrongo pilot for clarifying the appropriate elements of a community health-care program. The pilot approach was adapted from various initiatives that apply techniques of social learning to operational planning (Katz and Kahn 1978; Korten 1980; Simmons et al. 2002). Focus-group discussions with adult men, women, community leaders, and health workers were convened to assess participants' perceptions of service needs. The project's pilot services were implemented to adapt operational strategies to the climate of opinion expressed in the focus-group sessions. Focus groups were reconvened later and service strategies were modified to respond to the reactions of the community to the new health-care system (Nazzar et al. 1995).

In 1996, results of the pilot phase were used to guide the operational design of the Navrongo Community Health and Family Planning Project, a districtwide factorial experiment designed to test the relative impact of two general sets of existing underused resources for primary health care that had been identified.

The Navrongo design addresses the observation that traditional social institutions playing a powerful role in organizing village life were ignored by the health-service system. Chieftaincy, lineage, and social-network systems structure community leadership, social relationships, and collective action in Navrongo. Although political leaders instinctively turn to this traditional social system to mobilize votes, Ghana Health Service operations were organized without links to these institutions. The Navrongo experiment coordinated health-service delivery with traditional leaders, enabling health professionals to recruit, train, and deploy community-accountable volunteers, and enabling traditional leaders to monitor and support all community health-service operations. The Navrongo experiment was based on the hypothesis that mobilizing the traditional system of leadership, communication, and governance can develop health-care service accessibility and accountability and reduce mortality and fertility.

Failure of volunteer schemes in the past led some policymakers to be sceptical of any volunteer scheme and lent support to the view that only paid GHS paramedical staff 
could be effective workers in the community. In the early 1990s, community health nurses were trained for 18 months and assigned to subdistrict health centers throughout Ghana to provide malaria treatment and other child-health therapies, as well as childhood immunization, family planning, and health-education services. Although the nurses were hired to improve service accessibility, program coverage was limited by logistical problems, supervisory lapses, and resource shortages. The nurses were confined to Ghana Health Service subdistrict centers. The Navrongo experiment tested means of ending the social isolation of the nurses by retraining, renaming, and recertifying them as "community health officers" to serve as resident health-care providers.

Because the strategies for mobilizing traditional communities and for implementing the health-service system can work independently, jointly, or not at all, the Navrongo experiment is comprised of four experimental cells.

By 1997, evidence suggested that the Navrongo experiment was having an impact (Debpuur et al. 2002). A single nurse equipped with a motorbike and relocated to a village health center could outperform an entire subdistrict health center, increasing the volume of health-service encounters in study areas eightfold and improving immunization and family planning coverage. Fertility and mortality began to decline. The fertility impact of the combined service strategy was equivalent to the sum of the effects of the other cells. This particularly compelling cell of the experiment is known as the "Navrongo service model."

In response to preliminary evidence, the Ghana Health Service convened a national managers' conference in 1998 to deliberate on the implications of the Navrongo model for national policy and action and to review a draft statement declaring the Navrongo system as the national model for community-based health care.

\section{The Nkwanta Replication Project}

Practical experience with expanding the Navrongo model to other areas was first gained in Nkwanta District where new questions could be addressed concerning the transfer and sustainability of the model in a nonresearch setting. In 1999, the Ghana Health Service National Health Forum was convened to disseminate results from Navrongo and Nkwanta and to discuss a draft policy statement intended to legitimize the change process and sustain CHPS activity over time. An intermediate phase of policy 
implementation involved the creation of "lead districts" for expanding the number of sites where field orientation could be conducted.

\section{The Use of Research}

With the development of lead districts and the spread of the CHPS initiative to neighboring districts, questions arose regarding the pace and content of the change and whether undiagnosed operational problems were impeding progress. A monitoring system was launched to assess district-level progress by components of the change process and according to the smallest areal unit of a district where the initiative could be implemented (see bottom panel under Research in Figure 1). In 90-day cycles, monitoring results are distributed to every district by means of an electronic format that permits the display of maps showing CHPS coverage by component activity for every district in Ghana. In conjunction with the monitoring system, a qualitative arm involves focusgroup research based on discussions with panels of community members, frontline service workers, supervisors, and district leaders. With this approach, termed the "strategic assessment method," narrative diagnostic evidence is accumulated about problems hampering the progress of the CHPS program. Reports are reviewed by senior officials and presented at regional and national health meetings and conferences.

\section{THE DIFFUSION OF INNOVATION}

Ideas and innovations are spread through social networks via mechanisms collectively termed "diffusion." Social diffusion refers to the process of ideational or behavioral change fostered by social interaction. Organizational diffusion is an analogous process in which change can occur through the communication of ideas or the demonstration of new methods (Mintrom 1997). Component activities of the CHPS program have been designed to foster the diffusion of operational innovation (see Figure 1). Field demonstration and counterpart training are begun in one or more districts that have many zones where CHPS is operating. CHPS spreads rapidly once it starts within a district, but is constrained by the pace at which it spreads from district to district. CHPS activities are, therefore, designed to maximize the likelihood that the process of diffusion will begin, be sustained, and be amplified by program activities and resources. As many district teams as possible are 
exposed to lead-district activities, and the exposed district teams are encouraged to begin pilot activities within the district.

The concept of marshaling diffusion is grounded in the social science of institutional change. For four decades, social theorists have argued that diffusion theory is relevant to health and population policy because official action can be taken to accelerate the onset and pace of social change or expand the scope of informal diffusion processes (Rogers 1995). Diffusion theorists have also noted that exchange and interaction can lead to organizational change (Glaser et al. 1983). As Figure 1 shows, spontaneous organizational change grows from exposure to information about CHPS activities or exposure to the activities underway in Navrongo, Nkwanta, and the other lead districts. The Ghana Health Service program activities are designed to catalyze diffusion. The activities include the components described below.

\section{Consensus Building}

Activities designed to disseminate the results produced in Navrongo were conducted at national health-policy conferences attended by all district directors of medical services. They were designed to foster discussion and debate about the practical implications of the Navrongo findings, to present evidence gathered in Nkwanta that the Navrongo model would work elsewhere, and to note the consistency of the recommendations for change with the goals of the sector-wide approach. Senior political leaders and health officials were involved in these conferences to legitimize CHPS-sponsored changes and to lead the consensus-building process. Consensus-building activities are important for developing commitment to independent decentralized action, because without such commitment, district-management teams can question the feasibility, relevance, and value of CHPS for improving district health-service performance.

\section{Ownership}

Studies of the diffusion of organizational change have demonstrated that changes perceived as being brought from the outside are more difficult to introduce than are changes perceived to be owned by the host institution (Melgaard et al. 1998; Simmons et al. 2002). Researchers, as external actors with ideas about ways to improve opera- 
tions, structure, technology, or quality that emerge from controlled studies, small-scale pilot trials, or focused investigation, often work in isolation. Research-use schemes are developed to cajole the policy audience to take notice of what has been learned and to use the results. With CHPS, however, joint research-policymaker ownership of results was developed at the onset of the Navrongo program so that findings and change procedures would be natural outcomes of the investigation. To diminish the time lag between joint research-policy decisionmaking episodes, a routine collaborative review of results was developed. The Nkwanta demonstration was crucial to the concept of establishing Ghana Health Service ownership of the CHPS process, because the Navrongo project in isolation was regarded by many observers as an undertaking outside the usual administrative operation of the GHS, and its lessons were perceived in some quarters to be alien to the system into which they were to be absorbed.

\section{Change Agentry}

Effective change requires committed individuals who demonstrate that change is feasible and who represent the interests of change in the system at large. In some instances, change agents are external experts who are brought into the organization. An effective strategy requires balancing external agentry with internal ownership, however. For example, CHPS change agents are most effective when they are Ghana Health Service colleagues working with a team. In the case of CHPS, the most effective changeagent teams have been the study teams of the Navrongo Project, the Nkwanta District Health Management Team, and various regional health-administration teams that have fostered CHPS action or promoted program dissemination. This internal role of change agent has been an important and effective element of the CHPS program. Nonetheless, external agencies and individuals have also played a role as change agents, particularly when their technical assistance has been combined with financing for the changes they propose.

\section{Fostering the Spread of Change}

CHPS is designed to foster the replication of many pilot demonstration projects in multiple sites around the country rather than to structure a large-scale mechanistic 
replication of Navrongo. In a new phase of this work, launched in late 2002, innovators in the CHPS program are funded to invite other teams to review innovations, plan replication, and disseminate information about the success of the Navrongo experiment. With this approach, CHPS becomes a way to adapt service strategies to local realities and requirements. Achieving effective decentralization is important in Ghana, a country of 82 ethnolinguistic groups and profound regional cultural differences.

\section{Putting Success to Work}

The CHPS program has been informed by international experience demonstrating that change requires a success story to back it up (Glaser et al. 1983). Navrongo provides this function, not only as a source of research, but also as a site where teams can see the successful model in operation, interact with participants, and plan their own activities on the basis of a practical interchange with the people who make the Navrongo program work. Nkwanta is also providing practical demonstration of the CHPS initiative in action (Awoonor-Williams et al. 2002). Navrongo and Nkwanta continuously demonstrate the organizational model that CHPS represents and communicate lessons about elements of its success to all stakeholders.

\section{Credibility}

The CHPS initiative is based on the notion that diffusion of organizational change is likely to occur if a new activity represents a promising improvement on existing operations and if costs and operational changes are perceived to be feasible for district health-management teams to achieve (Phillips et al. 1984; Phillips 1988; Solo et al. 1998; Bertrand and Marin 2001).

\section{Feasibility}

Small-scale operations enable scientists to focus on a manageable agenda for change and to clarify what is required to undertake the change (Havelock 1978; Glaser et al. 1983). For the results of the Navrongo project to be credible, GHS had to perceive the changes suggested by research findings to be reasonable. If the findings had recommended a total structural change in operations, the recommendations would have been dismissed 
as unworkable. Costs of the project were transparent, and incremental investment in services was deliberately constrained, because an expensive research project with unaffordable activities and equipment would be of no use to the Ghana Health Service.

\section{System Demonstration}

Training is often proposed as a means of introducing organizational change. Two types of CHPS-sponsored training have been developed. "Horizontal" training involves convening workshops for a particular type of worker with sessions designed to upgrade the technical skills of participants. Frontline community-service workers are the mainstay of the CHPS initiative, and various international agencies are involved in upgrading workers' technical skills and improving the quality of care. Although horizontal training is useful in this regard, it is less effective than "hierarchical" training of implementation units for altering the structure and function of an organization. In the hierarchical approach, the staff in Navrongo, Nkwanta, or a lead district serve as role models for visiting counterpart teams comprised of the smallest operational unit for implementing the CHPS service system: the district director of health services, the district public health nurse, one subdistrict supervisor, and one or two community health officers. Each visitor is teamed with a counterpart for two weeks of practical, on-the-job demonstration of the new system so that he or she can help to set up a pilot program at home. When CHPS works well, visiting teams establish pilot demonstration zones for fostering diffusion and scaling up of the initiative among the remainder of the workforce in their home district, spreading activity to the grassroots level, where political and community support, and other resources can be aligned with the change process. Intervention is truly systemic when horizontal and hierarchical training are combined, linking the advantages of upgrading skills and service quality with the advantages of transferring operational change.

\section{Systemic Intervention}

In the CHPS program, all levels of the bureaucracy are involved in the change process, reflecting international experience showing that when elements of an organizational authority structure are bypassed, the chain of command is broken, inhibiting change 
(Glaser and Taylor 1973; Davis and Howden-Chapman 1996). Field operations of the Ghana Health Service are managed by teams of medical officers, paramedics, and public health nurses at the district and regional levels. In Accra, a senior management and policy team reports to the director general. In the CHPS example, attention was focused initially on building support at the central and district levels, but no clear role was developed for the regional health-management teams. This oversight hampered progress until it was corrected by involving regional leadership in key decisions and by building a consensus among regional directors of health services that CHPS was a key component of their plans of action. Thus, the CHPS experience suggests that the diffusion of innovation in health services is catalyzed by policies that promote interchange among implementers and innovators, provided that all levels of the organizational hierarchy are involved in the program.

\section{STRUCTURED ORganizational CHANGe}

The panel to the left in Figure 1 lists organizational activities that initiate, augment, and sustain the natural process of diffusion of innovation with guiding policies, standards, and directives. Improving access to health care is a critical aspect of poverty

alleviation, especially in the severely underdeveloped areas of the country; CHPS represents the contribution of the health sector to national poverty-alleviation policies. Fiveyear and annual budget plans address the staffing and financial requirements of implementing the CHPS program.

A CHPS task force has been convened by the Ghana Health Service Director General. The members of the task force are the GHS directors responsible for training and human resource development, health education, logistics and supplies, health administrative support, public health, clinical care, and monitoring and evaluation. Their mission is to integrate CHPS into the sector-wide approach rather than to establish a vertical program.

\section{Mobilizing Management Systems}

The dissemination activities of the CHPS initiative are incorporated into routine management operations. Staff meetings of the GHS directors, meetings of the regional health director with district health-management team staff, and national conferences of 
health managers all provide mechanisms for the review of CHPS activities, progress, and problems. Taken together, the Ghana Health Service divisions and the various routine staff meetings, correspondence, and conferences constitute a structure and communication process for legitimizing, implementing, monitoring, and evaluating the initiative's organizational change activities.

\section{Aligning Donor Support}

CHPS receives direct financial assistance for logistics and supplies from the Danish Agency for Development Assistance and support from the United States Agency for International Development for agencies engaged in monitoring and evaluation and in capacity building. Each agency works in collaboration with GHS directorates and relevant functional units.

As an adaptive strategy that responds to local needs, CHPS is not constrained to comply with a central plan for organizational change. Driven by diffusion, catalyzed by policy, and guided by research, CHPS advances the likelihood that findings from the Navrongo experiment will be put to national use.

\section{STAGES IN CHPS IMPLEMENTATION}

Launching CHPS requires new operational mechanisms for establishing community health-service accountability, service quality, and administrative control that are integrated into traditional institutions of village governance. Establishing these mechanisms involves six stages of organizational change (see Table 1):

(1) Preliminary planning. The fundamental operational unit of CHPS is the "zone," a geographic area where all CHPS services are phased in over time. Starting the CHPS process involves delineating zone boundaries, assessing manpower requirements and capacities, assessing equipment and training requirements, and scheduling the onset and frequency of nurses' visits to each household in every zone. CHPS implementation is enhanced if planning begins with a few of the most committed community health officers who serve as counterpart trainers for other workers in the district, drawing on their local experience to guide the within-district scaling-up process. Implementation teams have been trained in Navrongo in the practical means of starting the process-including 
Table 1 Operational contrasts between the existing clinic-based system and the CHPS community-based system

\begin{tabular}{|c|c|c|c|}
\hline \multirow[b]{2}{*}{ Stages } & \multicolumn{2}{|c|}{ Type of operation } & \multirow{2}{*}{$\begin{array}{l}\text { Requirements for } \\
\text { implementing the } \\
\text { CHPS system }\end{array}$} \\
\hline & Clinic-based system & CHPS system & \\
\hline Planning & $\begin{array}{l}\text { DHMT office-based } \\
\text { planning }\end{array}$ & $\begin{array}{l}\text { DHMT + traditional } \\
\text { leaders + community } \\
\text { health committees }\end{array}$ & $\begin{array}{l}\text { Building of community } \\
\text { awareness; outreach to } \\
\text { traditional leaders }\end{array}$ \\
\hline $\begin{array}{l}\text { Community } \\
\text { entry }\end{array}$ & $\begin{array}{l}\text { No community liaison; } \\
\text { biweekly/monthly } \\
\text { outreach clinics }\end{array}$ & $\begin{array}{l}\text { Initial liaison; } \\
\text { continuous outreach }\end{array}$ & $\begin{array}{l}\text { Community health- } \\
\text { committee selection; } \\
\text { entry training of } \\
\text { community health } \\
\text { officers; training of } \\
\text { community leaders }\end{array}$ \\
\hline $\begin{array}{l}\text { Creating } \\
\text { community } \\
\text { health } \\
\text { compounds }\end{array}$ & $\begin{array}{l}\text { None (subdistrict health } \\
\text { center and hospital } \\
\text { services) }\end{array}$ & $\begin{array}{l}\text { Community-donated } \\
\text { and constructed } \\
\text { community health } \\
\text { centers; community } \\
\text { homes }\end{array}$ & $\begin{array}{l}\text { Mobilization of } \\
\text { community for facility } \\
\text { development to create } \\
\text { community ownership } \\
\text { of primary service point }\end{array}$ \\
\hline $\begin{array}{l}\text { Procuring } \\
\text { equipment }\end{array}$ & $\begin{array}{l}\text { Four-wheel vehicle for } \\
\text { biweekly outreach clinics }\end{array}$ & $\begin{array}{l}\text { Bicycles or motorbikes } \\
\text { for officers' continuous } \\
\text { outreach }\end{array}$ & $\begin{array}{l}\text { Procurement; motorbike } \\
\text { rider training and } \\
\text { maintenance; capacity } \\
\text { building }\end{array}$ \\
\hline $\begin{array}{l}\text { Posting } \\
\text { community } \\
\text { health officers }\end{array}$ & $\begin{array}{l}\text { Subdistrict health center; } \\
\text { passive (facility-focused) }\end{array}$ & $\begin{array}{l}\text { Based at community } \\
\text { health center; } \\
\text { active (client-seeking) }\end{array}$ & $\begin{array}{l}\text { Officers mobilize } \\
\text { providers to visit } \\
\text { households; community } \\
\text { support of officers' } \\
\text { operations }\end{array}$ \\
\hline $\begin{array}{l}\text { Deploying } \\
\text { volunteers }\end{array}$ & $\begin{array}{l}\text { None or based on } \\
\text { disease-specific resource } \\
\text { availability }\end{array}$ & $\begin{array}{l}\text { Volunteers selected by } \\
\text { traditional leaders, } \\
\text { supervised by } \\
\text { community health } \\
\text { committees }\end{array}$ & $\begin{array}{l}\text { Training of community } \\
\text { leaders and community } \\
\text { health committees to } \\
\text { select and supervise } \\
\text { volunteers; training of } \\
\text { volunteers }\end{array}$ \\
\hline
\end{tabular}

DHMT $=$ District Health Management Team.

procedures for orienting frontline workers to the CHPS program. Training workshops have been convened for community health officers to upgrade clinical services, introduce techniques of community diplomacy, establish counseling methods, and develop midwifery skills. 
(2) Community entry. Community entry involves developing leadership and initial participation in the program through dialogue with community leaders and residents. Durbars, traditional gatherings that typically include drumming, dancing, speechmaking, public debate, and open discussion, are convened to foster open discussion of CHPS activities.

(3) Creating community health compounds. Community health services require a simple facility that provides a room for the community health officer's living area and another for a clinic. Developing such facilities contributes to community ownership of the CHPS initiative by involving leaders in planning and resource mobilization and volunteers for construction work.

(4) Procuring essential equipment. Launching services requires clinical equipment for primary-health-care service delivery and transportation equipment such as bicycles or motorbikes.

(5) Posting community health officers to the compounds. The most critical stage of the CHPS process is the launching of the community health officer component, which takes place at a durbar celebrating the onset of care. The officers' services involve provision of clinical sessions at the compound; making household visits to provide family planning services, health education, and ambulatory care; and implementing outreach clinics for childhood immunization.

(6) Deploying volunteers. Depending upon the district health-management team's decisions and upon local needs, volunteer health aides may be recruited by community health committees and provided with a six-week course in community health mobilization, with particular emphasis on promoting family planning and reproductive health among men. In some districts, the volunteers deliver health and family planning services. This work requires the training of volunteers and of the community health committee in pharmaceutical procurement and volunteer-program management, in keeping with the UNICEF-sponsored "Bamako initiative" (Knippenberg et al. 1990). Implementing the program involves a durbar for celebrating the creation of volunteer services, educating communities about referral services, and linking volunteer-based services with the activities of the local health officer and with clinical services at subdistrict health centers and district hospitals. 


\section{EVIDENCE OF ORganizational CHANGE}

Figure 2 portrays the geographic distribution of districts according to progress reports submitted to the Ghana Health Service Planning, Monitoring, and Evaluation Division as of December 31, 2000 and June 30, 2002. As the maps show, only 22 of 110 districts reported that they had begun CHPS implementation activities by the end of 2000. Eighteen months later, 87 districts reported that steps had been taken to launch the CHPS program. In 2000, CHPS progress was limited to the Upper East Region that includes Navrongo, Nkwanta District in the Volta Region, and to districts dispersed in the Ashanti, Brong Ahafo, Central, Eastern, Volta, and Western Regions that had sent representatives to a demonstration in Navrongo of community health and family planning services. By June 2002, the initiative had become a truly national commitment.

Although the number of districts joining the program is rapidly expanding, certain problems constrain program implementation. Figure 3 shows the geographic density of districts that had completed the stages described in Table 1 by June 30, 2000. Although about two-thirds of the districts report having completed community-based planning, relatively few have launched services. As Table 2 shows, 58 percent of the districts had yet to complete the process of community entry in any CHPS zone.

Table 2 Percentage of CHPS implementation zones among the 87 districts reporting initiation of CHPS activities (with zones and steps specified) to the CHPS Monitoring and Evaluation Secretariat, Ghana, June 30, 2002

\begin{tabular}{lcccccr}
\hline $\begin{array}{l}\text { Number of CHPS } \\
\text { zones that had } \\
\text { completed stage }\end{array}$ & $\begin{array}{c}\text { Community- } \\
\text { based } \\
\text { planning }\end{array}$ & $\begin{array}{c}\text { Community } \\
\text { entry }\end{array}$ & $\begin{array}{c}\text { Community } \\
\text { health center } \\
\text { construction } \\
\text { or renovation }\end{array}$ & $\begin{array}{c}\text { Community } \\
\text { health } \\
\text { officer } \\
\text { posting }\end{array}$ & $\begin{array}{c}\text { Essential } \\
\text { equipment } \\
\text { procurement deployment }\end{array}$ & $\begin{array}{c}\text { Volunteer } \\
\text { CHPS not started }\end{array}$ \\
\hline $0^{\text {a }}$ & 20.9 & 20.9 & 20.9 & 20.9 & 20.9 & 20.9 \\
1 & 13.6 & 58.2 & 42.7 & 62.8 & 60.0 & 71.9 \\
2 & 6.4 & 0.9 & 6.4 & 0.9 & 1.8 & 0.0 \\
$3-5$ & 11.8 & 1.8 & 5.5 & 1.8 & 1.8 & 0.0 \\
$6+$ & 21.8 & 7.3 & 10.9 & 3.6 & 5.5 & 3.6 \\
All & 25.5 & 10.9 & 13.6 & 10.0 & 10.0 & 3.6 \\
\hline
\end{tabular}

${ }^{a}$ Started CHPS, but had not completed the specified stage in any zone. 
Figure 2 Districts starting the CHPS implementation process, Ghana, December 31, 2000 and June 30, 2002

Districts where CHPS implementation process had begun by December 2000

Districts where CHPS started, steps specified (22)

Districts started, but with no zones or steps specified $(0)$

Districts reporting but CHPS not started (88)

Districts not reporting $(0)$

Districts where CHPS implementation process had begun by June 2002

Districts where CHPS started, steps specified (87)

Districts started, but with no zones or steps specified (0)

Districts reporting but CHPS not started (23)

Districts not reporting (0)
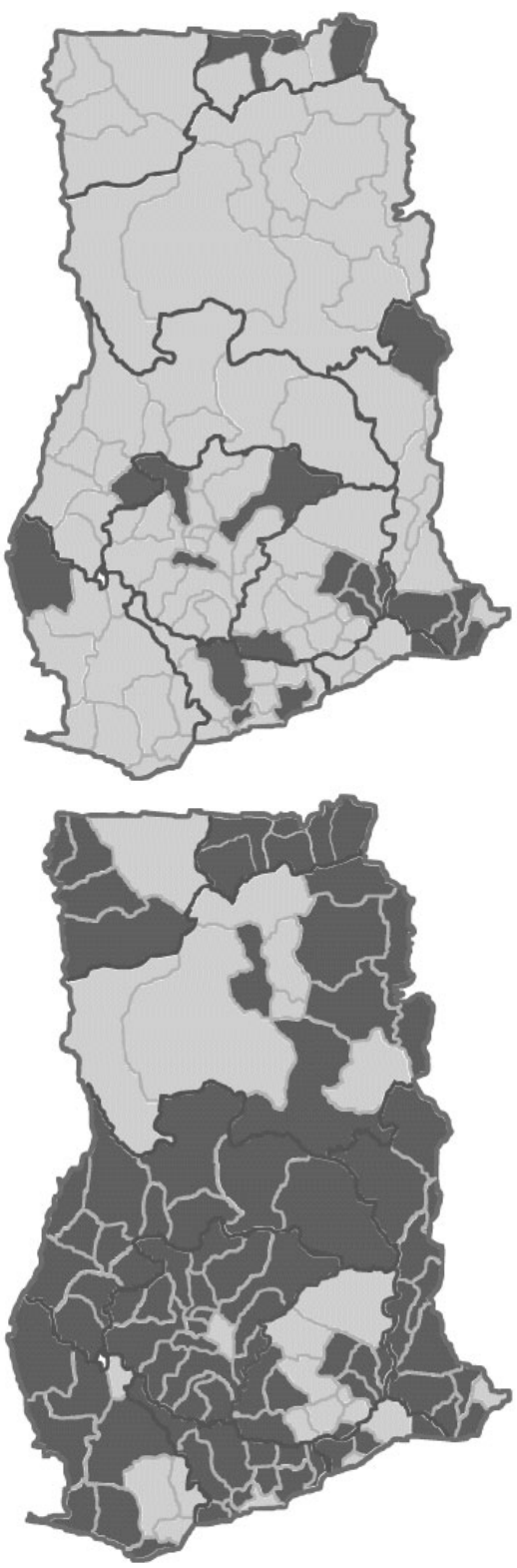
Figure 3 Geographic distribution of districts completing each of six CHPS implementation stages by June 30, 2000, Ghana
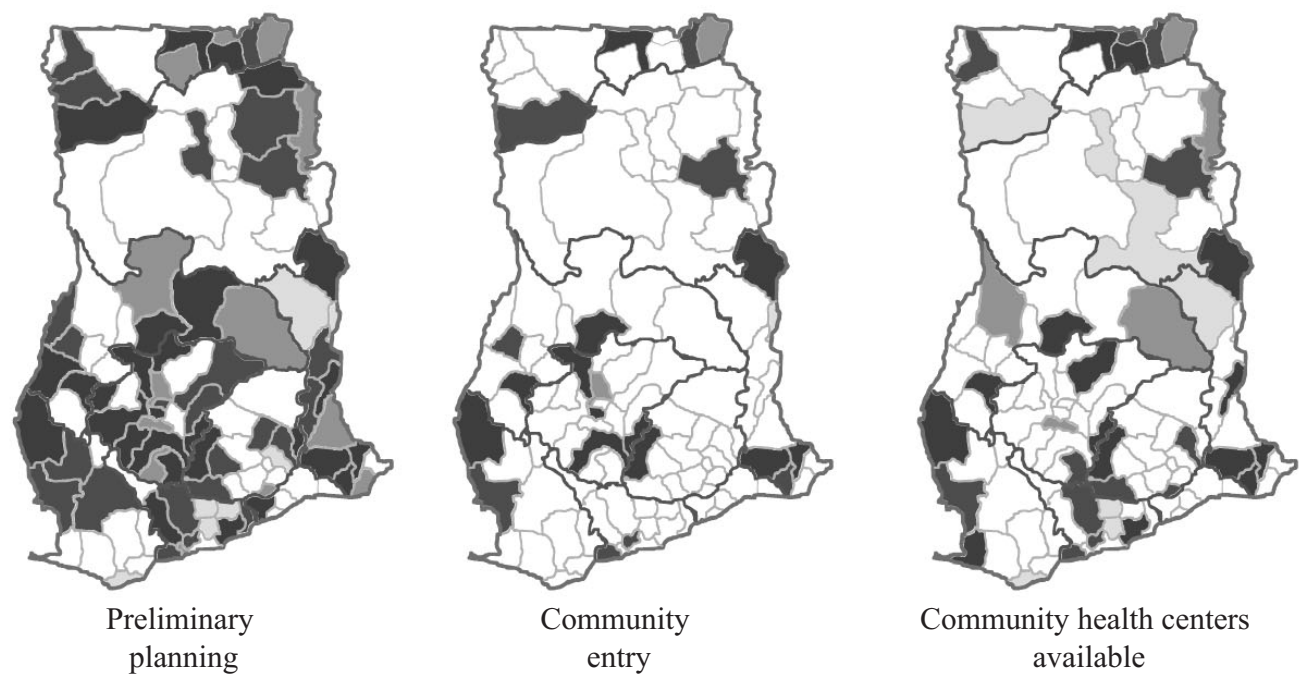

Community health centers available

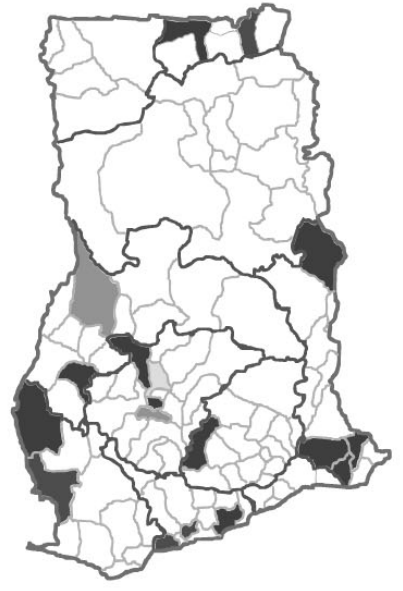

Community health officers posting completed

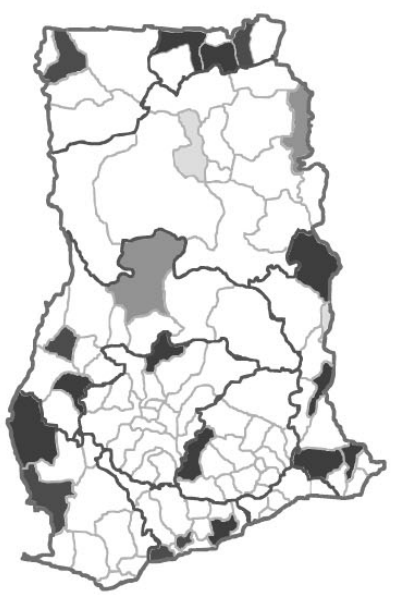

Essential equipment procured

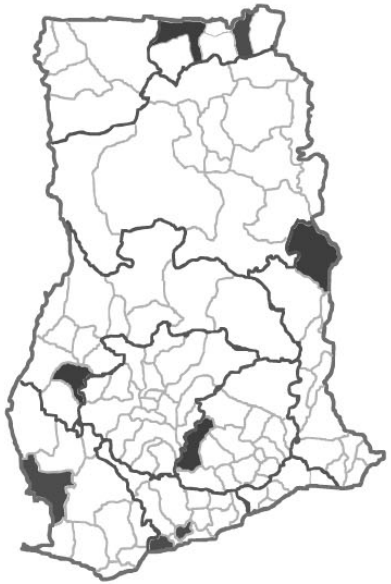

Volunteers deployed

Number of zones

$\square \quad 0$
$\square \quad 1$
$\square \quad 2$
$\square \quad 3-5$
$\square \quad 6+$


Districts starting the community-entry process, however, have typically implemented the program in more than two zones. Only two districts have limited community-entry activities to two CHPS zones; 18 percent of all districts have launched community entry in three or more zones. Surprisingly, completing construction of a community health center is more widespread than completing community entry, although resources required for construction are far greater than those required for community diplomacy. This finding, and other evidence from CHPS research, suggests that activities characteristic of the health bureaucracy are more readily scaled up than are activities that are new to the health sector.

Although progress is evident from the results shown in Table 2 and Figure 3, all activities other than community-based planning are confined to a few districts. For example, only 24 percent of all districts have more than three community health centers and only 14 percent of the districts have deployed three or more community health officers. The use of volunteers, a low-cost option for the program, is relatively rare, possibly because volunteers are not used unless other elements of the CHPS program are in place. Only 7 percent of the districts have three or more zones using volunteers.

National guidelines call for implementing the CHPS program in two lead districts in each region, each with two subdistricts that, in turn, have two implementation zones. This approach was intended to focus regional teams on building capacity for training, management, monitoring, and implementation before large-scale action is undertaken. This plan is referred to as the " 2 by 2 by 2 " formula. As Figure 3 shows, districts launching CHPS often deviate from this guideline, either by limiting pilot activity to a single zone, or by rapidly scaling up CHPS coverage to as many zones as resources permit in a short period of time. Where CHPS is advanced, the program has moved rapidly beyond the originally projected targets espoused by the formula. Few districts report one or two zones at a particular stage of operations, even for those stages that require capital investment, such as construction of a health center or equipment procurement. In Figure 3, the 28 districts participating in the program are shaded dark grey, denoting the large number of zones that are implementing the program in those districts, whereas only a few districts are shaded light grey (districts with few zones) and many are white (districts that have not reached a specified stage). Two scenarios 
thus characterize CHPS implementation: (1) Resource constraints and leadership problems often prevent the spread of CHPS activities from lead districts to other districts and (2) district leadership, diffusion of information, and grassroots political support favor rapidly scaling up CHPS once a given district launches the program.

Constrained diffusion between districts and rapid within-district diffusion is supported by contrasting focus-group interviews of workers not yet participating in the CHPS program who were asked to reflect on the implications of the CHPS initiative for their future work (Simmons et al. 1997; Nyonator et al. 2002). Their responses were compared with discussions among workers who are participating in the CHPS program. Nonparticipants express concerns about funding, the operational complexity of getting started, and the possible effects of community posting on staff morale. These concerns contrast with the views of district health-management team staff and workers exposed to the program who have learned that community resources are often more easily available than anticipated. Participating workers tend to be strong proponents of the program, alluding to the community support for their work and the professional gratification that it generates. This enthusiasm for the program spreads quickly among district health workers, villagers, and local politicians. The pace of the spread of information about CHPS is particularly rapid if funds other than those from team budgets are found to provide seed money for health center construction in one or two zones. All indications suggest that experience with the program catalyzes progress with its implementation, because political pressure for community-based care grows once services are demonstrably functioning, and workers' concerns are dissipated by their positive experience.

The monitoring of results and qualitative research indicate that local realities rather than central direction or policy typically dictate the pace and pattern of CHPS implementation. Reports suggest, moreover, that few districts are launching volunteer services, perhaps because volunteer effort is best conducted in the context of the presence of community health officers. Thus, although volunteer effort is a low-cost component of the CHPS program, the district health-managment teams defer the use of volunteers until other elements of the program are in place.

Human resource problems exacerbate constraints to CHPS implementation. Even if all available community nurses were trained and deployed, serious shortages would 
exist in many districts. The problem of turnover further complicates posting of community health officers. Nurses are assigned to districts after completing an 18-month course of study at one of three national training institutions, a procedure that does not necessarily insure that they will be posted to their home localities. A CHPS-oriented training program would select workers from the districts where they are to be posted and assign nurses to areas that are close to their homes. Such measures would address morale, housing, and language difficulties that sometime hinder CHPS operations.

Problems that arise in implementing the CHPS program must be assessed in the light of consistent evidence that the initiative is appreciated by the communities it serves. The most enthusiastic promoters of the program are communities that have benefited from CHPS services and workers who have developed a sense of pride in their capacity to serve the rural poor. CHPS, once implemented, is sustained by social and political support. For this reason, districts that adopt the program soon expand it more rapidly than health-sector resources can sustain it.

\section{CONCLUSION}

CHPS represents one of a few attempts made in Africa to draw upon findings from a research initiative to reform a national health-care program. Large-scale organizational change is a complicated undertaking, particularly in settings where internal resources for financing the process of change are lacking. It requires strategies for phasing in change by discrete components in small, manageable areal units. Pilot trials are useful, not only at the experimental phase, but also in the course of scaling up. Such trials build experience with the change process, permitting adaptation of the new organizational system to local realities. In this instance, the original Navrongo experimental trial and the Nkwanta replication site have been useful not only for producing scientific evidence that fostered the creation of CHPS but also for providing sites where CHPS implementation teams could visit and see the model in action, interact with its staff, and learn from on-the-job demonstrations of new roles and work routines.

The CHPS initiative is more than a series of practical steps and tasks; it is also a program grounded in organizational science and social learning. If CHPS succeeds, it will do so because it is fundamentally and intrinsically a Ghanaian initiative that engenders 
health-care reform by mobilizing support from social institutions and traditions. As such, CHPS is a bold departure from bureaucratic models for changing the way an organization operates; it represents a new and fundamentally African approach to organizational change by building consensus, marshaling local resources, and respecting indigenous institutions.

\section{REFERENCES}

Adjei, S., James F. Phillips, and T.C. Jones. 2002. "Utilization of evidence from experimental research to guide sector-wide health care reform in Ghana," paper presented at the 130th annual meeting of the American Public Health Association, Philadelphia, PA, November 9-13.

Awoonor-Williams, J., T.C. Jones, F. Nyonator, and James F. Phillips. 2002. "Utilizing successful research in community-based services with constrained resources: The Nkwanta experience catalysing organizational change in rural Ghana," Nkwanta District Health Administration. Unpublished.

Bertrand, Jane and C. Marin. 2001. "Operations research: Measuring its impact on service delivery and policy." Unpublished.

Binka, Fred N., Alex Nazzar, and James F. Phillips. 1995. “The Navrongo Community Health and Family Planning Project," Studies in Family Planning 26(3): 121-139.

Davis, P. and P. Howden-Chapman. 1996. "Translating research findings into health policy." Social Science \& Medicine 43(5): 865-872.

Debpuur, Cornelius, James F. Phillips, Elizabeth F. Jackson, Alex Nazzar, Pierre Ngom, and Fred N. Binka. 2002. "The impact of the Navrongo Project on contraceptive knowledge and use, reproductive preferences, and fertility." Studies in Family Planning 33(2): 141-164.

Glaser, Edward M. and S. Taylor. 1973. "Factors influencing the success of applied research." American Psychologist 28: 140-146.

Glaser, Edward M., Harold H. Abelson, and Kathalee N. Garrison. 1983. Putting Knowledge to Use: Facilitating the Diffusion of Knowledge and the Implementation of Planned Change. San Francisco: Jossey-Bass Publishers. 
Havelock, R. 1978. "What do we know from research about the process of research utilization?" Paper presented at the International Conference on Making Population/Family Planning Research Useful: The Communicators' Contribution. Honolulu: East-West Communication Institute, December 3-7.

Katz, David and Robert L. Kahn. 1978. The Social Psychology of Organizations. New York: John Wiley and Sons.

Knippenberg, R., D. Levy-Bruhl, R. Osseni, K. Drame, A. Soucat, and C. Debeugny. 1990. The Bamako Initiative: Primary Health Care. New York: UNICEF.

Korten, D. 1980. "Community organization and rural development: A learning process approach,” Public Administration Review September/October: 480-511.

Melgaard, B., A. Creese, B. Aylward et al. 1998. "Disease eradication and health systems development," Bulletin of the World Health Organization 76(supplement 2): $26-31$.

Ministry of Health of the Republic of Ghana (MOH). 1998. A Profile of Health Inequities in Ghana. Accra: MOH.

Mintrom, M. 1997. "Policy entrepreneurs and the diffusion of innovation," American Journal of Political Science 41(3): 738-770.

Nazzar, Alex, Philip B. Adongo, Fred N. Binka, James F. Phillips, and Cornelius Debpuur. 1995. "Developing a culturally appropriate family planning program for the Navrongo experiment," Studies in Family Planning 26(6): 307-324.

Nyonator, F., C. Agbadza, D. Gbeddy et al. 2002. "Community-based Health Planning and Services (CHPS) initiative in Ghana: A multi-level, qualitative assessment in the Volta Region," Ghana Health Service, Policy, Planning, Monitoring, and Evaluation Division. Unpublished report.

Pence, Brian, Philomena Nyarko, Fred N. Binka, James F. Phillips, and Cornelius Debpuur. 2001. "The impact of the Navrongo Community Health and Family Planning Project on child mortality, 1993-2000." Paper presented at the Global Conference of the International Union for the Scientific Study of Population, Salvador, Brazil, August. 
Phillips, James F. 1988. “Translating pilot project success into national policy development: Two projects in Bangladesh,” Asia-Pacific Population Journal 2(2): 3-28.

Phillips, James F., Ruth Simmons, George B. Simmons, and Md. Yunus. 1984. "Transferring health and family planning service innovations to the public sector: An experiment in organization development in Bangladesh," Studies in Family Planning 15(2): 62-73.

Rogers, Everett M. 1995. Diffusion of Innovations. Fourth edition. New York: Free Press.

Simmons, Ruth, Joseph Brown, and Margarita Díaz. 2002. "Facilitating large-scale transitions to quality of care: An idea whose time has come," Studies in Family Planning 33(1): 61-75.

Simmons, Ruth, Peter Hall, Juan Díaz, Margarita Díaz, Peter Fajans, and Jay Satia. 1997. "The strategic approach to contraceptive introduction," Studies in Family Planning 28(2): 79-94.

Solo, Julie, A.M. Cerulli, Robert A. Miller, Ian Askew, and E. Pearlman. 1998. "Strengthening the utilization of family planning OR: Findings from case studies in Africa." New York: Population Council. Unpublished report of the FRONTIERS Project. 


\section{POLICY RESEARCH DIVISION WORKING PAPERS}

Recent back issues available at www.popcouncil.org/publications/wp/prd/rdwplist.html.

144 John Bongaarts, "Household size and composition in the developing world."

145 John B. Casterline, Zeba A. Sathar, and Minhaj ul Haque, "Obstacles to contraceptive use in Pakistan: A study in Punjab."

146 Zachary Zimmer, Albert I. Hermalin, and Hui-Sheng Lin, "Whose education counts? The impact of grown children's education on the physical functioning of their parents in Taiwan."

147 Philomena Nyarko, Brian Pence, and Cornelius Debpuur, "Immunization status and child survival in rural Ghana."

*148 John Bongaarts and Zachary Zimmer, "Living arrangements of older adults in the developing world: An analysis of DHS household surveys."

149 Markos Ezra, "Ecological degradation, rural poverty, and migration in Ethiopia: A contextual analysis."
150 Cynthia B. Lloyd, Sahar El Tawila, Wesley H. Clark, and Barbara S. Mensch, "Determinants of educational attainment among adolescents in Egypt: Does school quality make a difference?"

*151 Barbara S. Mensch, Paul C. Hewett, and Annabel Erulkar, "The reporting of sensitive behavior among adolescents: A methodological experiment in Kenya."

152 John Bongaarts, "The end of the fertility transition in the developed world."

*153 Mark R. Montgomery, Gebre-Egziabher Kiros, Dominic Agyeman, John B. Casterline, Peter Aglobitse, and Paul Hewett, "Social networks and contraceptive dynamics in southern Ghana."

*154 Paul C. Hewett and Mark R. Montgomery, "Poverty and public services in developing-country cities."

* No longer available as a printed publication. Download electronic file from website only. 
155 Zachary Zimmer, Linda G. Martin, and Ming-Cheng Chang, "Changes in functional limitations and survival among the elderly in Taiwan: 1993, 1996, and 1999."

156 John Bongaarts and Griffith Feeney, "How long do we live?"

157 Zachary Zimmer and Sovan Kiry Kim, "Living arrangements and socio-demographic conditions of older adults in Cambodia."

158 Geoffrey McNicoll, "Demographic factors in East Asian regional integration."

159 Carol E. Kaufman, Shelley Clark, Ntsiki Manzini, and Julian May, "How community structures of time and opportunity shape adolescent sexual behavior in South Africa."

*160 Julia Dayton and Martha Ainsworth, "The elderly and AIDS: Coping strategies and health consequences in rural Tanzania."

161 John Bongaarts, "The end of the fertility transition in the developing world."
162 Naomi Rutenberg, Carol E. Kaufman, Kate Macintyre, Lisanne Brown, and Ali Karim, "Pregnant or positive: Adolescent childbearing and HIV risk in South Africa."

163 Barbara S. Mensch, Wesley H. Clark, and Dang Nguyen Anh, "Premarital sex in Vietnam: Is the current concern with adolescent reproductive health warranted?"

164 Cynthia B. Lloyd, Cem Mete, and Zeba A. Sathar, "The effect of gender differences in primary school access, type, and quality on the decision to enroll in rural Pakistan."

165 Kelly Hallman, Agnes R. Quisumbing, Marie Ruel, and Bénédicte de la Brière, "Childcare, mothers' work, and earnings: Findings from the urban slums of Guatemala City."

*166 Carol E. Kaufman and Stavros E. Stavrou, “'Bus fare, please': The economics of sex and gifts among adolescents in urban South Africa."

*167 Dominic K. Agyeman and John B. Casterline, "Social organization and reproductive behavior in southern Ghana."

\footnotetext{
* No longer available as a printed publication. Download electronic file from website only.
} 
168 Paul C. Hewett, Annabel S. Erulkar, and Barbara S. Mensch, "The feasibility of computer-assisted survey interviewing in Africa: Experience from two rural districts in Kenya."

169 Zachary Zimmer and Julia Dayton, "The living arrangements of older adults in sub-Saharan Africa in a time of HIV/AIDS."

170 Ravai Marindo, Steve Pearson, and John B. Casterline, "Condom use and abstinence among unmarried young people in Zimbabwe: Which strategy, whose agenda?"

171 Sajeda Amin and Nagah H. AlBassusi, "Wage work and marriage: Perspectives of Egyptian working women."

172 Zachary Zimmer, Napaporn Chayovan, Hui-Sheng Lin, and Josefina Natividad, "How indicators of socioeconomic status relate to physical functioning of older adults in three Asian societies."

173 Paul Demeny, "Population policy: A concise summary."

174 Geoffrey McNicoll, "Population and development: An introductory view."
175 James F. Phillips, Tanya C. Jones, Frank K. Nyonator, and Shruti Ravikumar, "Evidence-based development of health and family planning programs in Bangladesh and Ghana."

176 Cynthia B. Lloyd and Paul C. Hewett, "Primary schooling in sub-Saharan Africa: Recent trends and current challenges."

177 John Bongaarts, "Completing the fertility transition in the developing world: The role of educational differences and fertility preferences."

178 Elizabeth F. Jackson, Patricia Akweongo, Evelyn Sakeah, Abraham Hodgson, Rofina Asuru, and James F. Phillips, "Women's denial of having experienced female genital cutting in northern Ghana: Explanatory factors and consequences for analysis of survey data."

179 John Bongaarts and Griffith Feeney, "Estimating mean lifetime."

180 Frank K. Nyonator, J. Koku AwoonorWilliams, James F. Phillips, Tanya C. Jones, and Robert A. Miller, "The Ghana Community-based Health Planning and Services Initiative: Fostering evidence-based organizational change and development in a resource-constrained setting." 